\title{
Correction to: Behavioral responses to numerical differences when two invasive ants meet: the case of Lasius neglectus and Linepithema humile
}

\author{
Gema Trigos-Peral (D) - Sílvia Abril • Elena Angulo
}

Published online: 6 January 2021

(C) The Author(s) 2021

\section{Correction to: Biol Invasions}

https://doi.org/10.1007/s10530-020-02412-4

In the original publication of the article, one of the reference was published incorrectly. The correct reference is given in this correction.

The original article can be found online at https:// doi.org/10.1007/s10530-020-02412-4.

\section{G. Trigos-Peral ( $\square)$}

Museum and Institute of Zoology, Polish Academy of

Sciences, Warsaw, Poland

e-mail: getriral@gmail.com; gema_trigos@miiz.waw.pl

S. Abril

Departament de Ciències Ambientals, Universitat de

Girona, Girona, Spain

E. Angulo

Université Paris-Saclay, CNRS, AgroParisTech, Ecologie

Systématique et Evolution, Orsay, France

E. Angulo

Estación Biológica de Doñana, CSIC, Sevilla, Spain
Kleineidam CJ, Heeb EL, Neupert S (2017) Social interactions promote adaptive resource defense in ants. PLOS ONE 12(9):e0183872.

The original article has been corrected.

Publisher's Note Springer Nature remains neutral with regard to jurisdictional claims in published maps and institutional affiliations. 